\title{
Association of COL4A3 (rs55703767), MMP-9 (rs17576) and TIMP-1 (rs6609533) gene polymorphisms with susceptibility to type 2 diabetes
}

\author{
SAMIRA SARAVANI $^{1}$, DAVOOD YARI ${ }^{2}$, RAMIN SARAVANI $^{2,3}$ and CHANGIZ AZADI AHMADABADI ${ }^{4}$
}

\author{
${ }^{1}$ Department of Biology, Zabol University, Zabol 98615-538; ${ }^{2}$ Department of Clinical Biochemistry, \\ School of Medicine, Zahedan University of Medical Sciences, Zahedan 98167-43463; ${ }^{3}$ Cellular and Molecular Research \\ Center, ${ }^{4}$ Department of Cardiovascular Surgery, Zahedan University of Medical Sciences, Zahedan 98167-43463, Iran
}

Received December 9, 2016; Accepted January 23, 2017

DOI: 10.3892/br.2017.856

\begin{abstract}
Type 2 diabetes (T2D) is defined by high levels of glucose in the blood. The collagen IV level is associated with conditions of hyperglycemia and insulin resistance. Collagen type IV $\alpha 3$ chain (COL4A3) is a structural protein of the extracellular matrix (ECM). Matrix metallopeptidase 9 (MMP-9) is an enzyme that degrades the extracellular matrix and its activity is moderated by TIMP metallopeptidase inhibitor 1 (TIMP-1). The aim of the current study was to examine the association between genetic polymorphisms of COL4A3 (rs55703767), MMP-9 (rs17576) and TIMP-1 (rs6609533) in patients with T2D. This case-control study was performed on 120 Iranian patients with T2D and 120 healthy individuals. Genotypes were analyzed using the amplification refractory mutation system-polymerase chain reaction technique. The findings demonstrated significant differences between genotypic and allelic distributions of $C O L 4 A 3(\mathrm{G} / \mathrm{T})$ and MMP-9 (A/G) polymorphisms as follows: $C O L 4 A 3$ $(\mathrm{G} / \mathrm{T})$; TT vs. $\mathrm{GG}$, odds ratio $(\mathrm{OR})=0.235,95 \%$ confidence interval $(\mathrm{CI})=0.063-0.0802(\mathrm{P}=0.013)$ and $\mathrm{T}$ vs. $\mathrm{G}, \mathrm{OR}=0.592$, 95\% $\mathrm{CI}=0.371-0.943(\mathrm{P}=0.026) ; M M P-9(\mathrm{~A} / \mathrm{G}) ; \mathrm{AG}$ vs. $\mathrm{GG}$, $\mathrm{OR}=2.429,95 \% \mathrm{CI}=1.232-4.820(\mathrm{P}=0.008)$ and $\mathrm{A}$ vs. $\mathrm{G}$, $\mathrm{OR}=2.176,95 \% \mathrm{CI}=1.155-4.130(\mathrm{P}=0.013)$. No significant association was identified between TIMP-1 (A/G) polymorphism and T2D in females and males. Thus, the genotypic and allelic distributions of $C O L 4 A 3(\mathrm{G} / \mathrm{T})$ and $M M P-9(\mathrm{~A} / \mathrm{G})$ polymorphisms were associated with T2D. In addition, no significant association was identified in the genotypic distribution of the TIMP-1 (A/G) gene in females and in males. Further studies in other ethnic groups are required to confirm these findings.
\end{abstract}

Correspondence to: Dr Ramin Saravani, Cellular and Molecular Research Center, Zahedan University of Medical Sciences, Khalij Fars Boulevard, Zahedan 98167-43463, Iran

E-mail: saravaniramin@yahoo.com

Key words: collagen type IV $\alpha 3$ chain, gene polymorphism, matrix metallopeptidase 9, TIMP metallopeptidase inhibitor 1, type 2 diabetes

\section{Introduction}

Type 2 diabetes (T2D) is a metabolic disease, which is distinguished by high levels of blood sugar and occurs when the pancreas is unable to produce enough insulin or the body is unable to use the insulin that is produced (insulin resistance) $(1,2)$. The signs and symptoms of T2D include excessive urination, polydipsia, polyphagia, weight loss, blurry vision and fatigue $(3,4)$. The prevalence of diabetes has been estimated to increase from 171 million in 2000 to 366 million by 2030 and is associated with macro- and microvascular disorders $(3,5,6)$. T2D has numerous risk factors, including ageing, genetics, family history, previous gestational diabetes, ethnicity, nourishment and poverty $(3,7)$. As one of the most well-known polygenic diseases, certain candidate genes have been detected for the risks and complex traits of T2D (8). The extracellular matrix is important to the structure and function of various cell types; furthermore, it contributes to processes, such as cell adhesion, cellular proliferation, differentiation, migration and apoptosis (9). Type IV collagen is a structural glycoprotein and the primary component of basement membranes (BMs). Each collagen molecule comprises three chains $(10,11)$. In diabetes mellitus, marked alterations in the synthesis and structure of the extracellular matrix have been detected. A previous study has shown that collagen IV levels are associated with hyperglycemia and insulin resistance (12). Collagen type IV $\alpha 3$ chain (COL4A3) is expressed in the alveolar BM (13). It is located at position 2q35-q37 and contains 51 exons (14). Matrix metalloproteinases (MMP) are zinc-dependent endopeptidases that degrade matrix and non-matrix proteins (15). MMPs regulate numerous normal and pathological activities (16). The MMP-9 gene is located on chromosome 20q12.2-13.1 and contains 13 exons and 12 introns (17). The activities of MMPs are regulated by tissue inhibitors of metalloproteinases (TIMPs) (18). TIMP-1 is a secreted glycoprotein, which binds to active MMPs and inhibits their proteolytic activity $(19,20)$. In addition, TIMP-1 was mapped to X11p11.23-11.4 (21). The purpose of the current study was to investigate the possible association between T2D and COL4A3 (rs55703767, G/T), MMP-9 (rs17576, A/G) and TIMP-1 (rs6609533, A/G) gene polymorphisms in an Iranian population. 


\section{Materials and methods}

Subjects. This case-control study was performed on 120 patients with T2D and 120 healthy individuals. The mean ages were $56.34 \pm 10.8$ years. Approval was obtained from the ethics committee of Zahedan University of Medical Sciences (Zahedan, Iran) and written informed consent was obtained from all participants. T2D was diagnosed according to medical records and fasting blood glucose (FBG) levels using the American Diabetic association (ADA) criteria (22); our studies have been described previously $(23,24)$ and confirmed by at least two endocrinologists from the Diabetic Clinic at the Ali-Asghar Hospital (Zahedan, Iran). Healthy subjects were in good health and free of any comorbidity. Blood samples $(5 \mathrm{ml})$ were collected from all patients and controls after a 12-h fast (between 7:00 and 9:00 am), and stored in ethylenediaminetetraacetic acid-containing tubes for DNA extraction and measurement of clinical characteristics. The FBG, cholesterol, triglyceride (TG), high-density lipoprotein-cholesterol (HDL-C), low-density lipoprotein-cholesterol (LDL-C), creatinine, and urea are presented in Table I.

COL4A3, MMP-9 and TIMP-1 polymorphism genotyping. Genomic DNA was extracted from peripheral blood according to the salting-out method (25). The quality of the extracted DNA was confirmed using electrophoresis (at $80 \mathrm{~V}$ for $\sim 30-40 \mathrm{~min}$ ) on $2 \%$ agarose gel and the quantity of DNA by spectrophotometry (ratio, 260/280 nm; absorption, 1.7-1.9), the isolated DNA was stored at $-20^{\circ} \mathrm{C}$ until further use. The $\mathrm{COL} 4 A 3$ (rs55703767), MMP-9 (rs17576) and TIMP-1 (rs6609533) polymorphisms were genotyped using the amplification refractory mutation system polymerase chain reaction (ARMS-PCR) method.

Genotyping the rs55703767 polymorphism of the COL4A3 $(G / T)$ gene. Evaluation of the polymorphism, COL4A3 (rs55703767) was performed using ARMS-PCR (the primers) (Pishgam Biotech Co., Tehran, Iran) are presented in Table II. For this purpose, two tubes were used to define the variant as follows: Tube 1 contained wild-allele-specific reverse primer $\mathrm{G}$ and a common forward primer; tube 2 contained mutant-allele-specific reverse primer $\mathrm{T}$ and a common forward primer. PCR was performed in a final volume of $20 \mu \mathrm{l}$ using $2 \mu$ l genomic DNA, 7 DNase-free water (SinaClon BioScience Co., Tehran, Iran), $0.5 \mu l$ each primer and $10 \mu l$ Master Mix (Ampliqon A/S, Odense, Denmark). The amplification was performed with a primary denaturation step at $95^{\circ} \mathrm{C}$ for $5 \mathrm{~min}$, followed by 33 cycles at $95^{\circ} \mathrm{C}$ for $30 \mathrm{sec}, 54^{\circ} \mathrm{C}$ for $35 \mathrm{sec}$, and $72^{\circ} \mathrm{C}$ for $30 \mathrm{sec}$ with a final extension at $72^{\circ} \mathrm{C}$ for $10 \mathrm{~min}$. The PCR products were assayed by electrophoresis (at $50 \mathrm{~V}$ for $\sim 30-40 \mathrm{~min}$ ) on a $2 \%$ agarose gel and the product size was $216 \mathrm{bp}$.

Genotyping the rs17576 polymorphism of the MMP-9 $(A / G)$ gene. To detect the MMP-9 (rs17576) variant, two tubes were used as follows: Tube 1 contained wild-allele-specific forward primer $\mathrm{G}$ and a common reverse primer, and tube 2 contained mutant-allele-specific forward primer $\mathrm{A}$ and a common reverse primer. PCR was performed in a final volume of $20 \mu \mathrm{l}$ using $1 \mu 1$ each primer, $10 \mu 1$ Master Mix, $2 \mu 1$ genomic DNA
Table I. Demographic characteristics of T2D patients.

\begin{tabular}{lccc}
\hline Characteristic & $\begin{array}{c}\text { T2D } \\
(\mathrm{n}=120)\end{array}$ & $\begin{array}{c}\text { Controls } \\
(\mathrm{n}=120)\end{array}$ & P-value \\
\hline $\begin{array}{l}\text { Age }(\text { years }) \\
\text { Gender }(\mathrm{f} / \mathrm{m})\end{array}$ & $\begin{array}{c}56.57 \pm 10.602 \\
91 / 29\end{array}$ & $\begin{array}{c}56.11 \pm 11.075 \\
88 / 32\end{array}$ & 0.744 \\
$\begin{array}{l}\text { Duration of illness } \\
\text { (years) }\end{array}$ & $9.91 \pm 6.90$ & - & - \\
Fasted blood sugar & $172.51 \pm 77.32$ & $75.53 \pm 12.04$ & 0.001 \\
(mg/dl) & & & \\
TG $(\mathrm{mg} / \mathrm{dl})$ & $152.47 \pm 73.50$ & $120.25 \pm 10.12$ & 0.001 \\
TC $(\mathrm{mg} / \mathrm{dl})$ & $175.79 \pm 38.29$ & $190.09 \pm 15.04$ & 0.001 \\
HDL-C $(\mathrm{mg} / \mathrm{dl})$ & $59.02 \pm 6.74$ & $60.36 \pm 4.53$ & 0.116 \\
LDL-C $(\mathrm{mg} / \mathrm{dl})$ & $89.82 \pm 13.00$ & $90.22 \pm 6.03$ & 0.878 \\
Urea $(\mathrm{mg} / \mathrm{dl})$ & $31.33 \pm 10.95$ & $30.23 \pm 6.12$ & 0.185 \\
Creatinine $(\mathrm{mg} / \mathrm{dl})$ & $1.02 \pm 0.264$ & $1.01 \pm 0.233$ & 0.352 \\
\hline
\end{tabular}

T2D, type 2 diabetes; TG, triglyceride; TC, total cholesterol; HDL-C, high-density lipoprotein-cholesterol; LDL-C, low-density lipoprotein-cholesterol; $\mathrm{f}$, female; $\mathrm{m}$, male.

and $6 \mu$ DNase-free water and the PCR cycling condition were as follows: Primary denaturation at $95^{\circ} \mathrm{C}$ for $5 \mathrm{~min}$, followed by 30 cycles at $95^{\circ} \mathrm{C}$ for $30 \mathrm{sec}, 53^{\circ} \mathrm{C}$ for $25 \mathrm{sec}$, and $72^{\circ} \mathrm{C}$ for $30 \mathrm{sec}$ with a final extension at $72^{\circ} \mathrm{C}$ for $5 \mathrm{~min}$. The PCR products were assayed by electrophoresis (at $50 \mathrm{~V}$ for $\sim 30-40 \mathrm{~min}$ ) on a $2 \%$ agarose gel and the product size was $275 \mathrm{bp}$.

Genotyping the rs6609533 polymorphism of the TIMP-1 $(A / G)$ gene. DNA amplification was performed using two tubes. Tube 1 contained wild-allele-specific forward primer A and a common reverse primer, and tube 2 contained mutant-allele-specific forward primer $\mathrm{G}$ and a common reverse primer. PCR was performed in a final volume of $20 \mu \mathrm{l}$ using $0.5 \mu 1$ each primer, $10 \mu 1$ Master Mix, $2 \mu 1$ genomic DNA and $7 \mu 1$ DNase-free water. The PCR cycling conditions were as follows: Primary denaturation at $95^{\circ} \mathrm{C}$ for $5 \mathrm{~min}$, followed by 32 cycles at $95^{\circ} \mathrm{C}$ for $30 \mathrm{sec}, 61^{\circ} \mathrm{C}$ for $25 \mathrm{sec}$, and $72^{\circ} \mathrm{C}$ for $35 \mathrm{sec}$ with a final extension at $72^{\circ} \mathrm{C}$ for $5 \mathrm{~min}$. The PCR products were assayed by electrophoresis (at $50 \mathrm{~V}$ for $\sim 30-40 \mathrm{~min}$ ) on a $2 \%$ agarose gel and the product size was $306 \mathrm{bp}$.

Statistical analysis. The statistical analysis of the data was calculated using the SPSS version 19.0 software (IBM SPSS, Armonk, NY, USA). The association between genotypes and T2D was assayed by calculating the OR and 95\% CI using the $\chi^{2}$ test. $\mathrm{P}<0.05$ was considered to indicate a statistically significant difference. In addition, Hardy Weinberg equilibrium (HWE) was calculated through comparison between observed and expected frequencies of genotypes associated with the investigated polymorphisms.

\section{Results}

Study population. The case and control groups were matched regarding age (patient group: $56.57 \pm 10.602$ years; control 
Table II. Primers used for the identification of SNPs.

\begin{tabular}{|c|c|c|c|}
\hline SNP & Orientation & Sequence (5'-3') & $\begin{array}{c}\text { Amplicon } \\
\text { size (bp) }\end{array}$ \\
\hline \multirow[t]{3}{*}{ COL4A3 (rs55703767) G/T } & $\mathrm{R}(\mathrm{G}$ allele $)$ & AGGATTACCTTAATGCCACC & \multirow{3}{*}{216} \\
\hline & $\mathrm{R}$ (T allele) & AGGATTACCTTAATGCCACA & \\
\hline & $\mathrm{F}$ (universal) & CTGCATTTGGGAATCATAGT & \\
\hline \multirow[t]{3}{*}{$M M P-9(\mathrm{rs} 17576) \mathrm{A} / \mathrm{G}$} & $\mathrm{F}(\mathrm{A}$ allele $)$ & CCCAGGACTCTACACCAA & \multirow{3}{*}{275} \\
\hline & $\mathrm{F}(\mathrm{G}$ allele $)$ & CCCAGGACTCTACACCAG & \\
\hline & $\mathrm{R}$ (universal) & GTGGAAAGACAAACTGATGG & \\
\hline \multirow[t]{3}{*}{ TIMP-1 (rs6609533) A/G } & $\mathrm{F}(\mathrm{A}$ allele $)$ & CTGTGTCCAATACCGTGTGATAA & \multirow{3}{*}{306} \\
\hline & $\mathrm{F}(\mathrm{G}$ allele $)$ & CTGTGTCCAATACCGTGTGATAG & \\
\hline & $\mathrm{R}$ (universal) & GGCTTCAAGATAGTCACTGG & \\
\hline
\end{tabular}

SNP, single nucleotide polymorphism; COL4A3, collagen type IV $\alpha 3$ chain; MMP-9, matrix metallopeptidase 9; TIMP-1, TIMP metallopeptidase inhibitor 1 ; F, forward; R, reverse.

Table III. Genotype and allele frequencies of selected polymorphisms in COL4A3,MMP-9 and TIMP-1 genes.

\begin{tabular}{|c|c|c|c|c|}
\hline SNP & Patients, n (\%) & Controls, $\mathrm{n}(\%)$ & OR $(95 \% \mathrm{CI})$ & P-value \\
\hline \multicolumn{5}{|c|}{ COL4A3 (rs55703767) G/T } \\
\hline GG & $83(69.2)$ & $73(60.8)$ & Ref. & - \\
\hline GT & $33(27.5)$ & $32(26.7)$ & $1.1(0.593-2.05)$ & 0.769 \\
\hline TT & $4(3.3)$ & $15(12.5)$ & $0.235(0.063-0.0802)$ & 0.013 \\
\hline \multicolumn{5}{|c|}{ Allele frequency } \\
\hline G & 199 (82.9) & $178(74.1)$ & Ref. & - \\
\hline $\mathrm{T}$ & $41(17)$ & $62(25.8)$ & $0.592(0.371-0.943)$ & 0.026 \\
\hline \multicolumn{5}{|c|}{$M M P-9(\mathrm{rs} 17576) \mathrm{A} / \mathrm{G}$} \\
\hline GG & $84(70)$ & $102(85)$ & Ref. & - \\
\hline AG & $36(30)$ & $18(15)$ & $2.429(1.232-4.820)$ & 0.008 \\
\hline AA & 0 & 0 & - & 1.000 \\
\hline \multicolumn{5}{|c|}{ Allele frequency } \\
\hline $\mathrm{G}$ & $204(85)$ & $222(92.5)$ & Ref. & - \\
\hline A & $36(15)$ & $18(7.5)$ & $2.176(1.155-4.130)$ & 0.013 \\
\hline \multicolumn{5}{|c|}{ TIMP-1 (rs6609533) A/G in females } \\
\hline AA & $27(29.7)$ & $27(30.7)$ & Ref. & - \\
\hline AG & $44(48.3)$ & $25(28.4)$ & $1.760(0.852-3.634)$ & 0.126 \\
\hline GG & $20(22)$ & $36(40.9)$ & $0.556(0.259-1.192)$ & 0.131 \\
\hline \multicolumn{5}{|c|}{ Allele frequency } \\
\hline A & $98(53.8)$ & $79(44.9)$ & Ref. & - \\
\hline $\mathrm{G}$ & $84(46.2)$ & $97(55.1)$ & $0.698(0.461-1.058)$ & 0.092 \\
\hline \multicolumn{5}{|c|}{ TIMP-1 (rs6609533) A/G in males } \\
\hline AA & $17(58.6)$ & $15(46.9)$ & Ref. & - \\
\hline GG & $12(41.4)$ & $17(53.1)$ & $0.62(0.23-1.72)$ & 0.360 \\
\hline
\end{tabular}

$\mathrm{P}<0.05$ was considered to indicate statistically significant differences. SNP, single nucleotide polymorphism; OR, odds ratio; CI, confidence interval; COL4A3, collagen type IV $\alpha 3$ chain; $M M P-9$, matrix metallopeptidase 9; TIMP-1, TIMP metallopeptidase inhibitor 1.

group: $56.11 \pm 11.075 ; \mathrm{P}=0.744$ ) and gender [patient group $($ female $/$ male $)=91 / 29$ and control group $($ female $/$ male $)=88 / 32$; $\mathrm{P}=0.767]$ (Table I).
Frequency of the COL4A3 (rs55703767) genetic polymorphism. Table III presents the allelic and genotypic distributions of the COL4A3 (rs55703767), MMP-9 (rs17576) and TIMP-1 
Table IV. Single nucleotide polymorphism association with T2D patients and control subjects.

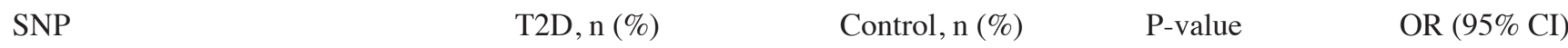

COL4A3 (rs55703767) G/T

Dominant

GG

$\mathrm{GT}+\mathrm{TT}$

$83(69.2)$

$37(30.8)$

Recessive

GG + GT

TT

$116(96.7)$

$4(3.3)$

87 (72.5)

$33(27.5)$

Overdominant

$\mathrm{GG}+\mathrm{TT}$

GT

TIMP-1 (RS6609533) A/G

Dominant

$\begin{array}{ll}\mathrm{AA} & 39(32.5) \\ \mathrm{AG}+\mathrm{GG} & 81(67.5)\end{array}$

Recessive

$\mathrm{AA}+\mathrm{AG}$

GG

83 (69.2)

37 (30.8)

$76(63.3)$

44 (36.7)
73 (60.8)

47 (39.2)

0.18

$0.69(0.41-1.18)$

$105(87.5)$

$15(12.5)$

0.0068

$0.24(0.07-0.75)$

88 (73.3)

$32(26.7)$

0.88

$1.04(0.59-1.85)$

44 (36.7)

$76(63.3)$

0.498

$1.202(0.706-2.048)$

$69(57.5)$

$51(42.5)$

0.062

$0.603(0.355-1.025)$

95 (79.2)

25 (20.8)

0.062

$0.603(0.355-1.025)$

$\mathrm{P}<0.05$ was considered to indicate a statistically significant difference. T2D, type 2 diabetes; OR, odds ratio; CI, confidence interval; OR, odds ratio; CI, confidence interval; COL4A3, collagen type IV a3 chain; MMP-9, matrix metallopeptidase 9; TIMP-1, TIMP metallopeptidase inhibitor 1.

(rs6609533) polymorphisms in the patients and control subjects. The frequency distribution of the COL $4 A 3(\mathrm{G} / \mathrm{T})$ genotypes in T2D patients were as follows: GG, 69.2\%; GT, 27.5\%; and TT, $3.3 \%$ and the distribution in the controls were: GG, $60.8 \%$; GT, 26.7\%; and TT, $12.5 \%$. Statistically significant differences concerning the genotypic distribution of the COL4A3 polymorphism (rs55703767) were identified. The frequency of the TT genotype was significantly different between the patients and the control subjects $(\mathrm{OR}=0.235,95 \% \mathrm{CI}=0.063-0.0802$; $\mathrm{P}=0.013)$. In addition, a statistically significant difference in the $\mathrm{T}$ allele frequency was observed between patients with T2D and the control subjects $(\mathrm{OR}=0.592,95 \% \mathrm{CI}=0.371-0.943$; $\mathrm{P}=0.026)$. These results demonstrated that the COL $4 A 3$ (rs55703767) polymorphism was associated with T2D.

Frequency of the MMP-9 (rs17576) genetic polymorphism. In the current study, the allelic and genotypic distributions of the MMP-9 (rs17576) polymorphism were significantly different between the T2D patients and control subjects. Significant differences in the distribution of the AG genotype frequency were observed in the patients with T2D and the healthy individuals $(\mathrm{OR}=2.429,95 \% \mathrm{CI}=1.232-4.820 ; \mathrm{P}=0.008)$. The current findings indicated that the AG genotype increased the risk of susceptibility to T2D. The AA genotype was not observed in the current study. Furthermore, a statistically significant difference was identified in the A allele frequency $(\mathrm{OR}=2.176,95 \% \mathrm{CI}=1.155-4.130 ; \mathrm{P}=0.013)$. The $\mathrm{A}$ allele was a risk factor for susceptibility to T2D.

Frequency of the TIMP-1 (rs6609533) genetic polymorphism. The TIMP-1 gene is located on the $\mathrm{X}$ chromosome; therefore, males and females were analyzed separately. No significant difference in the distribution of the AG genotype frequency was identified between the T2D patients and control subject groups in females. In addition, no significant difference in distribution of the genotype frequency was identified for TIMP-1 (A/G) in males. Furthermore, no statistically significant differences were identified in the allele frequencies in females.

The Hardy-Weinberg equilibrium (HWE) of the COL4A3, MMP-9 and TIMP-1 polymorphism were evaluated using the $\chi^{2}$ test for each of the single nucleotide polymorphisms (SNPs) as follows: $C O L 4 A 3$ (case; $\mathrm{P}=0.748, \chi^{2}=0.1$, control; $\mathrm{P}<0.05$, $\chi^{2}=11.1$ ), MMP-9 (case; $\mathrm{P}=0.0532, \chi^{2}=3.74$, control; $\mathrm{P}=0.374$, $\chi^{2}=0.79$ ), and TIMP -1 (case; $\mathrm{P}<0.05, \chi^{2}=8.52$, control; $\mathrm{P}<0.05$, $\left.\chi^{2}=40.63\right)$.

Dominant, recessive and overdominant model analyses were performed (Table IV) for the COL4A3 (rs55703767) G/T and the TIMP-1 (RS6609533) A/G, and the result indicated that, of the COL4A3 (rs55703767) G/T, the TT genotype was associated with $\mathrm{T} 2 \mathrm{D}$ in the recessive model $(\mathrm{P}=0.0068)$ while, 
in TIMP-1 (RS6609533) A/G, the AG genotype was associated with T2D in the overdominant model $(\mathrm{P}=0.062)$. No significant association with T2D was identified in the other models.

\section{Discussion}

T2D is a growing health challenge worldwide and is the most widespread form of diabetes (26). T2D is characterized by hyperglycemia and results from a combination of resistance to insulin action and insufficient insulin secretion (27). Previous studies demonstrated that genetic polymorphisms may reveal individual differences in T2D risk (28). Type IV collagen is a major component of the ECM and various different physiological situations, including ageing, diabetes, scarring, and fibrosis are associated with it (29); in T2D, the biosynthesis of type IV collagen is increased (30). The levels of extracellular matrix components are a reflection of the balance between the rate of synthesis and the degradation of matrix proteins. Degradation is attained through MMPs, which are regulated by TIMPs (9). Alterations in connective tissue metabolism may associate with the development of diabetic complications, such as neuropathy, nephropathy and retinopathy (12). Rana et al (31) proposed that thin BM nephropathy (TBMN) results from mutations in $C O L 4 A 3$. Numerous different $C O L 4 A 3$ mutations cause TBMN and the identification of polymorphisms in this gene is particularly important (31). Hou et al (32) identified that a novel mutation $(3725 \mathrm{G}>\mathrm{A}, \mathrm{G} 1242 \mathrm{D})$ of $\mathrm{COL} 4 \mathrm{~A} 3$ exerted an underlying pathogenic role in the heterozygous form in TBMN (29). Ahluwalia et al (33) demonstrated that MMP-9 polymorphisms were associated with the risk of diabetic nephropathy (DN). Nazir et al (34) found that genetic variants of MMP-9 had a significant positive association with $\mathrm{DN}$ and that this gene may contribute to the pathophysiology of DN (34). The results of Pan et al (35) indicated that the TIMP-1 SNPs, rs4898 and rs6609533 were associated with an increased risk of early aseptic loosening susceptibility (35). Kumar et al (36) observed that the SNP rs6609533 of the TIMP-1 gene interacted with pim-3 proto-oncogene, serine/threonine kinase, resulting in a possible risk for the development of chronic obstructive pulmonary disease (36).

In conclusion, the $\mathrm{T}$ allele of $C O L 4 A 3(\mathrm{G} / \mathrm{T})$ (with a protective role) and the A allele of $M M P-9(\mathrm{~A} / \mathrm{G})$ (as a risk factor) were associated with T2D. However, no significant association was identified between the $\mathrm{G}$ allele of TIMP-1 (A/G) and the risk/protective characteristics of $\mathrm{T} 2 \mathrm{D}$ in females in the evaluated population. However, further studies with larger sample sizes and various ethnic groups are required to confirm these findings.

\section{Acknowledgements}

The present study was funded by a dissertation grant (grant no. 7224) from the Deputy for Research, University of Medical Sciences (Zahedan, Iran).

\section{References}

1. Galavi HR, Saravani R, Alamdari AR, Ranjbar N, Damani E and Khodakhier TN: Evaluating the Effect of the rs2229238 and the rs4845625 Interleukin 6 Receptor Gene Polymorphisms on Body Mass Index and the Risk of Type 2 Diabetes in an Iranian Study Population. Int J High Risk Behav Addict 5: e33289, 2016.
2. Matough FA, Budin SB, Hamid ZA, Alwahaibi N and Mohamed J: The role of oxidative stress and antioxidants in diabetic complications. Sultan Qaboos Univ Med J 12: 5-18, 2012.

3. McNaughton D: 'Diabesity' down under: Overweight and obesity as cultural signifiers for type 2 diabetes mellitus. Crit Public Health 23: 274-288, 2013.

4. Saravani S, Miri H, Saravani R, Yari D, Nakhaee A and Mahjoubifard M: Association of catalase (rs7943316) and glutathione peroxidase-1 (rs1050450) polymorphisms with the risk of type 2 diabetes (T2DM). Mol Gen Microbiol Virol 30: 216-220, 2015.

5. Lakhan SE and Kirchgessner A: The emerging role of dietary fructose in obesity and cognitive decline. Nutr J 12: 114, 2013.

6. Azmy R, Dawood A, Kilany A, El-Ghobashy Y, Ellakwa AF and El-Daly M: Association analysis of genetic variations of eNOS and $\alpha 2 \beta 1$ integrin genes with type 2 diabetic retinopathy. Appl Clin Genet 5: 55-65, 2012.

7. Saravani R, Esmaeeli E, Tamendani MK and Nejad MN: Oxytocin Receptor Gene Polymorphisms in Patients With Diabetes. Gene, Cell and Tissue 2: e27904, 2015.

8. Tang L, Wang L, Liao Q, Wang Q, Xu L, Bu S, Huang Y, Zhang C, Ye H, Xu X, et al: Genetic associations with diabetes: Meta-analyses of 10 candidate polymorphisms. PLoS One 8: e70301, 2013

9. Khan T, Muise ES, Iyengar P, Wang ZV, Chandalia M, Abate N, Zhang BB, Bonaldo P, Chua S and Scherer PE: Metabolic dysregulation and adipose tissue fibrosis: Role of collagen VI. Mol Cell Biol 29: 1575-1591, 2009.

10. Heidet L, Arrondel C, Forestier L, Cohen-Solal L, Mollet G, Gutierrez B, Stavrou C, Gubler MC and Antignac C: Structure of the human type IV collagen gene COL4A3 and mutations in autosomal Alport syndrome. J Am Soc Nephrol 12: 97-106, 2001.

11. Saravani R, Hasanian-Langroudi F, Validad MH, Yari D, Bahari G, Faramarzi M, Khateri M and Bahadoram S: Evaluation of possible relationship between COL4A4 gene polymorphisms and risk of keratoconus. Cornea 34: 318-322, 2015.

12. Muona P, Jaakkola S, Zhang RZ, Pan TC, Pelliniemi L, Risteli L, Chu ML, Uitto J and Peltonen J: Hyperglycemic glucose concentrations up-regulate the expression of type VI collagen in vitro. Relevance to alterations of peripheral nerves in diabetes mellitus. Am J Pathol 142: 1586-1597, 1993.

13. Kim KM, Park SH, Kim JS, Lee WK, Cha SI, Kim CH, Kang YM, Jung TH, Kim IS and Park JY: Polymorphisms in the type IV collagen $\alpha 3$ gene and the risk of COPD. Eur Respir J 32: 35-41, 2008.

14. Stabuc-Šilih M, Ravnik-Glavač M, Glavač D, Hawlina M and Stražišar M: Polymorphisms in COL4A3 and COL $4 A 4$ genes associated with keratoconus. Mol Vis 15: 2848-2860, 2009.

15. Marson BP, Lacchini R, Belo V, Mattos SG, da Costa BP, Poli-de-Figueiredo CE and Tanus-Santos JE: Functional matrix metalloproteinase (MMP)-9 genetic variants modify the effects of hemodialysis on circulating MMP-9 levels. Clin Chim Acta 414: 46-51, 2012.

16. Kowluru RA, Zhong Q and Santos JM: Matrix metalloproteinases in diabetic retinopathy: Potential role of MMP-9. Expert Opin Investig Drugs 21: 797-805, 2012.

17. Wu HD, Bai X, Chen DM, Cao HY and Qin L: Association of Genetic Polymorphisms in Matrix Metalloproteinase-9 and Coronary Artery Disease in the Chinese Han Population: A Case-Control Study. Genet Test Mol Biomarkers 17: 707-712, 2013.

18. Nagase H, Visse R, Murphy G, Cao H-y and Qin L: Structure and function of matrix metalloproteinases and TIMPs. Cardiovasc Res 69: 562-573, 2006.

19. Rivera S, Tremblay E, Timsit S, Canals O, Ben-Ari Y and Khrestchatisky M: Tissue inhibitor of metalloproteinases-1 (TIMP-1) is differentially induced in neurons and astrocytes after seizures: Evidence for developmental, immediate early gene, and lesion response. J Neurosci 17: 4223-4235, 1997.

20. Goldbergova MP, Parenica J, Jarkovsky J, Kala P, Poloczek M, Manousek J, Kluz K, Kubkova L, Littnerova S, Tesak M, et al: The association between levels of tissue inhibitor of metalloproteinase-1 with acute heart failure and left ventricular dysfunction in patients with ST elevation myocardial infarction treated by primary percutaneous coronary intervention. Genet Test Mol Biomarkers 16: 1172-1178, 2012.

21. Brew $\mathrm{K}$ and Nagase H: The tissue inhibitors of metalloproteinases (TIMPs): An ancient family with structural and functional diversity. Biochimica et Biophysica Acta (BBA). Mol Cell Res 1803: 55-71, 2010. 
22. Association AD; American Diabetes Association: Standards of medical care in diabetes. Diabetes Care 27 (Suppl 1): S15-S35, 2004.

23. Saravani R, Irani $\mathrm{Z}$ and Galavi HR: Evaluation of transcription factor 7 like 2 polymorphisms and haplotypes in risk of type 2 diabetes. Rev Rom Med Lab 24: 423-430, 2016.

24. Saravani R, Galavi HR, Ranjbar N and Alamdari A: ATP-binding cassette transporter A1 polymorphisms and haplotypes in risk of type 2 diabetes. Gene, Cell and Tissue 4: e43677, 2016.

25. Mousavi M, Saravani R, Modrek MJ, Shahrakipour M and Sekandarpour S: Detection of Toxoplasma gondii in Diabetic Patients Using the Nested PCR Assay via RE and B1 Genes. Jundishapur Journal of Microbiology 9: e29493, 2016.

26. Ghoshal K and Bhattacharyya M: Adiponectin: Probe of the molecular paradigm associating diabetes and obesity. World J Diabetes 6: 151-166, 2015.

27. Tripathi BK and Srivastava AK: Diabetes mellitus: Complications and therapeutics. Med Sci Monit 12: RA130-RA147, 2006.

28. Staiger H, Machicao F, Stefan N, Tschritter O, Thamer C Kantartzis K, Schäfer SA, Kirchhoff K, Fritsche A and Häring HU: Polymorphisms within novel risk loci for type 2 diabetes determine $\beta$-cell function. PLoS One 2: e832, 2007.

29. Osman OS, Selway JL, Harikumar PE, Stocker CJ, Wargent ET, Cawthorne MA, Jassim S and Langlands K: A novel method to assess collagen architecture in skin. BMC Bioinformatics 14: 260, 2013.

30. Sternberg M, Grigorova-Borsos AM, Guillot R, Kassab JP, Bakillah A, Urios P, Cohen-Forterre L, Mozère G, André J, Leblond V, et al: Changes in collagen type IV metabolism in diabetes. C R Seances Soc Biol Fil 187: 247-257, 1993 (In French)
31. Rana K, Tonna S, Wang YY, Sin L, Lin T, Shaw E, Mookerjee I and Savige J: Nine novel COL4A3 and COL4A4 mutations and polymorphisms identified in inherited membrane diseases. Pediatr Nephrol 22: 652-657, 2007.

32. Hou P, Chen Y, Ding J, Li G and Zhang H: A novel mutation of COL4A3 presents a different contribution to Alport syndrome and thin basement membrane nephropathy. Am J Nephrol 27: 538-544, 2007

33. Ahluwalia TS, Khullar M, Ahuja M, Kohli HS, Bhansali A, Mohan V, Venkatesan R, Rai TS, Sud K and Singal PK: Common variants of inflammatory cytokine genes are associated with risk of nephropathy in type 2 diabetes among Asian Indians. PLoS One 4: e5168, 2009.

34. Nazir N, Siddiqui K, Al-Qasim S and Al-Naqeb D: Meta-analysis of diabetic nephropathy associated genetic variants in inflammation and angiogenesis involved in different biochemical pathways. BMC Med Genet 15: 103, 2014.

35. Pan F, Hua S, Luo Y, Yin D and Ma Z: Genetic susceptibility of early aseptic loosening after total hip arthroplasty: The influence of TIMP-1 gene polymorphism on Chinese Han population. J Orthop Surg 9: 108, 2014.

36. Kumar M, Bhadoria DP, Dutta K, Singh S, Gupta J, Kumar R, Chhillar AK, Yadav V, Singh B and Sharma GL: Combinatorial effect of TIMP-1 and $\alpha 1$ AT gene polymorphisms on development of chronic obstructive pulmonary disease. Clin Biochem 44: 1067-1073, 2011 